\title{
pH Affects Properties of Green Banana Starch ${ }^{1}$
}

\author{
Edelmiro J. Rodriguez-Sosa and Orlando Parsi-Ros ${ }^{2}$
}

\begin{abstract}
The effect of $\mathrm{pH}$ on the pasting properties and swelling power of $\mathrm{V}-2390$ and Montecristo green bananas (Musa acuminata $\times$ M. balbisiana AAB) cultivars was studied. Initial viscosity of starch slurries acidified at different pH levels with citric acid varied from $78^{\circ}$ to $84^{\circ} \mathrm{C}$. At pH 2.50 and 3.00 the starch gel lost much of its properties while being cooked at $95^{\circ} \mathrm{C}$. However, at pH suitable for canning as acidified food ( 3.50 to 4.50 ) banana starch showed sufficient strength to maintain shape and texture as influenced by the starch. Starch was also relatively stable while submitted to prolonged periods of heating and when cooled and maintained at temperatures at which it might be regularly used. Swelling power increased as temperature increased, but was somewhat low for both cultivars. Banana starch granules were irregular in shape and size.
\end{abstract}

\section{INTRODUCTION}

Banana (Musa accuminata $\times$ M. balbisiana AAB) is an important food crop in tropical areas and is extensively cultivated in Puerto Rico. Montecristo is the most important banana cultivar grown in Puerto Rico, but it is susceptible to the leaf fungus known as sigatoka (black spot). However, cultivar V-2390 is not susceptible to this fungus.

In Puerto Rico bananas are consumed either as a fresh fruit when ripe or as a vegetable when green. When eaten green, they are boiled in salt water. This treatment changes the textural characteristics of green banana's most important constitutent: the starch. These changes, presumably, are even greater when processed.

Study of the recorder rheological data gives valuable information on the physical changes that may be expected during the processing of products containing starch. The Amylograph-Viscograph has been the instrument most extensively used to measure the changes in consistency which occur when heating, cooking and cooling starch.

The rheological properties of starch can be modified by materials such as salt, fat, sugars, proteins and gums (8). Haydar et al. (6) found that a gradual substitution of hydrogen or alkaline cations in starch phosphate groups with $\mathrm{Ca}$ or $\mathrm{Mg}$ decreased starch swelling power, water binding capacity, viscosity, and solubilization. Other authors have described the effect of sugar, inorganic salts and other compounds on pasting properties of starch $(2,5,7,11,13)$. According to Schoch (17) the viscosity of a

${ }^{1}$ Manuscript submitted to Editorial Board September 9, 1983.

${ }^{2}$ Food Technologist and Research Assistant, respectively, Food Technology Laboratory, Agricultural Experiment Station, Mayagüez Campus, University of Puerto Rico, Río Piedras, P.R. 
starch paste may be reduced by blending at high speed, by applying high shear forces, by heating at high temperatures, by treatment with hot caustic alkali, and enzymes, and by treatment with acids.

Cowie and Greenwood (8) found that $0.2 \mathrm{M} \mathrm{HCl}$ at $45^{\circ} \mathrm{C}$ did not change the granular structure of potato starch, but that both the amylose and the amylopectin component were degraded. They also found that in spite of the fact that the potato starch did not change its granular structure it dispersed more readily to form a less viscous paste. Rodriguez Sosa et al. (15), working with the pasting properties of yam (Dioscorea rotundata) starch slurries at different $\mathrm{pH}$ levels, found that, except at $\mathrm{pH} 3.00$, yam starch was stable when cooked at $50^{\circ} \mathrm{C}$ for $1 \mathrm{~h}$. They also found that at $\mathrm{pH} 3.00$ and after reaching $95^{\circ} \mathrm{C}$ the starch slurries thin down to zero viscosity losing all their gel properties and never retrograde.

When starch is heated in water, the granules swell and a portion of the starch substance dissolves in the surrounding aqueous medium. The degree of swelling and the amount of solubles will depend on the starch species, type and the degree of modification. Kasiyu et al. (9) found that at high concentrations banana (Valery var.) starch, as cereal starches, exhibits a two-stage swelling pattern, but that the second stage was not pronounced. Rodriguez-Sosa and Parsi-Ros (4) found that the swelling power of Habanero yam starch increased after $60^{\circ} \mathrm{C}$ being relatively high at $95^{\circ} \mathrm{C}$.

Greenwood and Thomson (4) found that banana starch granules were oval with a granule size of $35 \mu \mathrm{m}$, but Kayisu (9) found that banana starch granules were irregular in shape with spheroids and elongated forms predominating. The granules varied from 15 to $40 \mu \mathrm{m}$ for the spheroid type, the elongated granules were 7 to $25 \mu \mathrm{m}$ wide and 20 to 50 $\mu \mathrm{m}$ long.

\section{MATERIALS AND METHODS}

Banana starch used in this experiment was extracted by the method described by Badenhuisen (1). The starch was dehydrated in a vacuum oven at $60^{\circ} \mathrm{C}$ for 24 hours and placed in a desiccator until used.

The consistency measurements of starch pastes, commonly referred to as viscosity, were obtained with an Amylograph-Viscograph. The starch slurries were prepared in the Amylograph bowl with $27 \mathrm{~g}$ of starch to 450 $\mathrm{ml}$ distilled water (6\% aqueous solution) at $\mathrm{pH} 2.50,3.00,3.50,4.00,4.50$, $5.00,5.50$ adjusted with citric acid. The mixtures thus obtained were stirred for $5 \mathrm{~min}$ at $200 \mathrm{r} / \mathrm{min}$ in the Amylograph for thorough mixing, and then stirred for 5 additional $\mathrm{min}$ at $75 \mathrm{r} / \mathrm{min}$. The initial temperature for the heating-cooling cycle was $30^{\circ} \mathrm{C}$; the $700 \mathrm{~cm} / \mathrm{g}$ cartridge was used in all measurements. Temperature was increased at $1.5^{\circ} \mathrm{C} / \mathrm{min}$ up to $95^{\circ}$ 
$\mathrm{C}$ and held constant for $1 \mathrm{~h}$. Samples were then cooled at the same rate to $50^{\circ} \mathrm{C}$ and held at that temperature for another hour.

The swelling power of the granular starches was determined with the method described by Schoch (16), and granule size by the method of MacMasters (10).

The data obtained on the amylographic and swelling power were submitted to analysis of variance and Duncan's multiple range test (12).

\section{RESULTS AND DISCCUSION}

Table 1 shows the pasting properties of V-2390 and Montecristo banana starch slurries. Initial viscosity of the starch slurries for both

TABLE 1.-Consistency properties of green V-2390 and Montecristo banana starch slurries on heating at different $\mathrm{pH}$ levels as measured with the Brabender Amylograph-Viscograph

\begin{tabular}{lrrrrrrrr}
\hline \multicolumn{1}{c}{ Properties } & \multicolumn{7}{c}{$\mathrm{pH}$ levels } \\
\cline { 2 - 8 } & 2.50 & 3.00 & 3.50 & 4.00 & 4.50 & 5.00 & 5.50 \\
\hline & & & 70 & V-2390 & & \\
Initial viscosity $(\mathrm{BU})^{1}$ & 10 & 8 & 10 & 10 & 10 & 10 & 10 \\
Gelatinization temperature $\left({ }^{\circ} \mathrm{C}\right)$ & 78 & 78 & 79.5 & 79.5 & 79.5 & 78 & 81 \\
Viscosity at $95^{\circ} \mathrm{C}$ & 118 & 290 & 405 & 380 & 445 & 438 & 265 \\
Maximum viscosity at $95^{\circ} \mathrm{C}$ & 220 & 303 & 425 & 425 & 483 & 495 & 478 \\
Viscosity after $1 \mathrm{~h}$ at $95^{\circ} \mathrm{C}$ & 0 & 33 & 223 & 293 & 413 & 450 & 455 \\
Viscosity at $50^{\circ} \mathrm{C}$ & 0 & 33 & 290 & 360 & 560 & 623 & 658 \\
Viscosity after $1 \mathrm{~h}$ at $50^{\circ} \mathrm{C}$ & 0 & 35 & 275 & 385 & 518 & 520 & 585 \\
& & & & Montecristo & & \\
& 10 & 10 & 10 & 10 & 10 & 5 & 10 \\
Initial velocity & 78 & 79.5 & 79.5 & 82.5 & 82.5 & 82.5 & 84 \\
Gelatinization temperature $\left({ }^{\circ} \mathrm{C}\right)$ & 220 & 255 & 253 & 240 & 220 & 225 & 220 \\
Viscosity at $95^{\circ} \mathrm{C}$ & 243 & 310 & 353 & 390 & 435 & 458 & 478 \\
Maximum viscosity at $95^{\circ} \mathrm{C}$ & 8 & 55 & 193 & 293 & 390 & 438 & 470 \\
Viscosity after $1 \mathrm{~h}$ at $95^{\circ} \mathrm{C}$ & 8 & 60 & 230 & 368 & 513 & 593 & 648 \\
Viscosity at $50^{\circ} \mathrm{C}$ & 5 & 63 & 210 & 328 & 445 & 513 & 573 \\
Viscosity after $1 \mathrm{~h}$ at $50^{\circ} \mathrm{C}$ & & & & & & & \\
\hline
\end{tabular}

${ }^{1}$ Brabender Units.

cultivars was about the same. Gelatinization temperatures from $\mathrm{pH} 4.00$ to 5.50 of Montecristo cultivar were somewhat higher, indicating a degree of resistance to swelling at these $\mathrm{pH}$ levels.

Viscosity measurements of V-2390 banana were only slightly higher than those of cultivar Montecristo indicating that the susceptibility to acid treatment is about the same for both cultivars. Except for "Viscosity at $95^{\circ} \mathrm{C}$ " (table 1), viscosity measurements of starch of both cultivars increased as $\mathrm{pH}$ increased, showing that swelling capacity was higher at higher $\mathrm{pH}$ levels.

Maximum viscosity or swelling capacity was attained after $95^{\circ} \mathrm{C}$, but 
this maximum was not a viscosity peak. At the concentration used in this experiment, banana starch granules swelled very little. Low swelling indicates a strong internal bonding. Banana starch also resisted mechanical disintegration at intermediate $\mathrm{pH}$ levels. This resistance could explain the absence of peak viscosity and the slight increase in viscosity during cooking (fig. 1). Generally speaking, the swelling capacity of V2390 cultivar was somewhat higher than that of Montecristo.

At $\mathrm{pH} 2.50$ and 3.00 viscosity measurements of starch of both banana cultivars decreased substantially when heated at $95 \% \mathrm{C}$ denoting that the starch molecules suffered a great solubilization. At these $\mathrm{pH}$ levels banana starch slurries lost practically all their gel properties. The degree of solubilization (maximum viscosity minus viscosity after $1 \mathrm{~h}$ at $95^{\circ} \mathrm{C}$ )

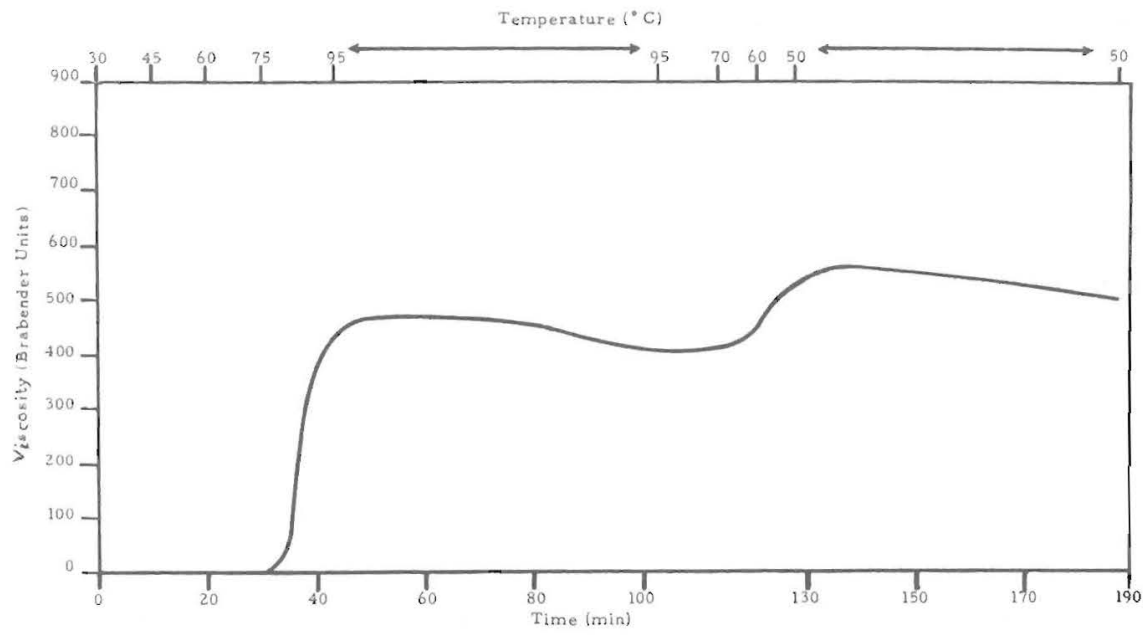

Fig. 1.-A typical amylogram of green banana (Musa acuminata $\times$ balbisiana AAB).

increased as $\mathrm{pH}$ decreased. This can be explained in terms of hydrolytic or oxidative cleavage that probably takes place in the more accessible intermicellar areas when granular starch is treated with acid. Acid treatment causes a weakening of the network within the granule. Thus, the granules fragmented and showed an increase in solubilization during pasting.

The retrogradation or reaggregation tendency (viscosity at $50^{\circ} \mathrm{C}$ minus viscosity after $1 \mathrm{~h}$ at $95^{\circ} \mathrm{C}$ ) of starch granules of both banana cultivars increased with the increase in $\mathrm{pH}$. The starch of both cultivars was relatively stable while being cooked at $95^{\circ} \mathrm{C}$ and at $50^{\circ} \mathrm{C}$. This indicates that at $\mathrm{pH}$ levels suitable for canning acidified green bananas (3.50 to 4.00) starch showed sufficient strength to maintain the characteristic banana texture as influenced by starch. 
Viscosity measurements of starch slurries at $\mathrm{pH} 2.50$ were the lowest in both banana cultivars and were significantly different $(\mathrm{P}=.05)$ from all others except from that at $\mathrm{pH} 3.00$. There were no significant differences in starch slurries of the two cultivars among samples at $\mathrm{pH}$ levels $4.50,5.00$, and 5.50. Also, no significant differences were found in viscosity measurements of samples at $\mathrm{pH}$ levels $3.50,4.00$, and 4.50 in cultivar $\mathrm{V}$-2390 nor between samples at pH levels 3.50 and 4.00 in cultivar Montecristo, but in Montecristo a significant difference was observed between starch slurries at $\mathrm{pH} 3.50$ and 4.50 .

Swelling power of starch of both cultivars increased as temperature increased (table 2). However, within the limits of this study, it seems TABLE 2.-Swelling power of green $V-2390$ and Montecristo banana starch at different $p H$ levels and temperature

\begin{tabular}{rrrrrrrr}
\hline \multirow{2}{*}{ Temperatures } & \multicolumn{7}{c}{ pH levels } \\
\cline { 2 - 7 } & 2.50 & 3.00 & 3.50 & \multicolumn{1}{c}{4.00} & 4.50 & 5.00 & 5.50 \\
\hline${ }^{\circ} \mathrm{C}$ & & & \multicolumn{7}{c}{ V-2390 } & & & \\
60 & 2.61 & 2.32 & 2.92 & 2.52 & 2.71 & 2.58 & 2.47 \\
65 & 2.85 & 2.36 & 2.92 & 2.88 & 2.94 & 3.13 & 3.37 \\
70 & 5.82 & 4.12 & 5.58 & 6.54 & 5.61 & 5.31 & 5.70 \\
75 & 8.79 & 7.01 & 7.09 & 7.68 & 7.44 & 7.13 & 7.17 \\
80 & 9.32 & 7.93 & 8.79 & 8.65 & 8.28 & 8.85 & 8.09 \\
85 & 11.89 & 9.09 & 9.32 & 9.21 & 9.88 & 10.01 & 9.24 \\
90 & 13.20 & 9.58 & 11.87 & 11.17 & 11.47 & 11.49 & 10.42 \\
95 & 20.86 & 11.68 & 13.71 & 14.44 & 11.73 & 13.70 & 12.56 \\
& & & & Montecristo & & & \\
60 & 6.85 & 4.25 & 4.51 & 2.81 & 3.63 & 3.17 & 3.30 \\
65 & 8.04 & 7.14 & 7.04 & 5.33 & 6.11 & 6.15 & 6.60 \\
70 & 9.71 & 8.46 & 7.80 & 7.17 & 7.76 & 8.28 & 7.76 \\
75 & 14.16 & 8.68 & 13.81 & 8.95 & 9.68 & 9.06 & 9.54 \\
80 & 16.77 & 10.50 & 11.30 & 10.48 & 10.73 & 10.14 & 10.50 \\
85 & 24.34 & 12.51 & 12.67 & 12.01 & 12.52 & 12.19 & 11.67 \\
90 & 27.96 & 14.86 & 15.88 & 13.92 & 13.14 & 14.06 & 14.55 \\
95 & 37.21 & 24.26 & 21.93 & 16.27 & 16.90 & 17.36 & 18.61 \\
\hline
\end{tabular}

that swelling power depends on temperature but not on $\mathrm{pH}$. Thus, no definite trend was observed regarding the relationship between $\mathrm{pH}$ and swelling power.

Swelling power at $\mathrm{pH} 2.50$ was the highest and significantly different from that of all other $\mathrm{pH}$ levels. However, no significant differences were found among samples at other $\mathrm{pH}$ levels. At pasting or gelatinization temperature of banana starch $\left( \pm 80^{\circ} \mathrm{C}\right.$ ) and at $95^{\circ} \mathrm{C}$ (maximum cooking temperature) swelling power for both cultivars was somewhat low. Swelling power at 90 and $95^{\circ} \mathrm{C}$ for both cultivars was significantly different between the two and significantly different from that of other tempera- 
tures. According to Schoch (7), $85^{\circ} \mathrm{C}$ is the optimum single-point characterization for determining swelling power of starches. In Montecristo cultivar, swelling power at $85^{\circ} \mathrm{C}$ was significantly different from that at all other temperatures. In cultivar V-2390, no significant difference was observed between samples at $80^{\circ}$ and $85^{\circ} \mathrm{C}$. In the two cultivars there were no significant differences between samples at $75^{\circ}$ and $80^{\circ} \mathrm{C}$.

Starch granules of both cultivars were irregular in shape; at the same time oval, spherical and elongated granules appeared. Granules were also of irregular sizes; the average granule size of V-2390 was $33.4 \mu \mathrm{m}$; of Montecristo it was $28 \mu \mathrm{m}$. The range in size in both cultivars was from 10 to $85 \mu \mathrm{m}$.

\section{RESUMEN}

Se estudió el efecto del $\mathrm{pH}$ sobre la pastosidad y la hinchazón del almidón de guineo verde (Musa acuminata $\times$ M. balbisiana AAB) de las cultivares V-2390 y Montecristo. Las medidas de pastosidad se tomaron con un amiloviscógrafo. Las mezclas acuosas de almidón se prepararon añadiendo a $450 \mathrm{ml}$ de agua destilada $27 \mathrm{~g}$ de almidón y ajustando el pH con ácido cítrico a $2.50,3.00,3.50,4.00,4.50,5.00$ y 5.50. La viscosidad inicial de las muestras varió de $78^{\circ}$ a $84^{\circ} \mathrm{C}$. A los niveles de $\mathrm{pH} 2.50 \mathrm{y}$ 3.00 el gel de almidón perdió casi todas sus propiedades al calentarlo prolongadamente a $95^{\circ} \mathrm{C}$. Sin embargo, a los niveles adecuados para enlatar el guineo verde como un producto acidificado (3.50 y 4.50), el almidón mostró suficiente fortaleza para mantener la forma y textura del guineo según las influye el almidón. El almidón también fue relativamente estable cuando se sometió a periodos prolongados de calentamiento y enfriamiento y también se mantuvo a las temperaturas en que regularmente se utiliza. El poder de hinchazón del gránulo de almidón aumentó según aumentó la temperatura, pero esta medida fue bastante baja en ambas cultivares. Los gránulos del almidón de guineo son irregulares en forma y tamaño. El tamaño medio fue de $33.44 \mu \mathrm{m}$ y $28 \mu \mathrm{m}$ en las cultivares $\mathrm{V}$ 2390 y Montecristo, respectivamente.

\section{LITERATURE CITED}

1. Badenhuisen, N. P., 1964. Methods in Carbohydrates Chemistry, Vol IV: 14-15, Academic Press, New York, N. Y.

2. Bean, M. L. and Osman, E. M., 1959. Behavior of starch during food preparation. II. Effect of different sugars on the viscosity and gel strength of starch pastes, Food Res. 24: 265.

3. Cowie, J. M. G. and Greenwood, C. T., 1957. Physico-chemical Studies on Starches. Part V. The effect of acid on potato starch granules, J. Chem. Soc. Part III. 2658.

4. Greenwood, C. T. and Thomson, J., 1962. Physico-chemical Studies on Starches. Part XXIV. The fractionation and characterization of starches of various plant origins, J. Chem. Soc. 222-9. 
5. Harai, J., Zaehringer, M. V. and Weise, A. C., 1970. Properties of wheat starch pastes containing components of cheddar whey, Food Technol. 24 (7): 803-5.

6. Haydar, M., Moledina, K., Ooraikul, B. and Hadziyev, D., 1980. Effect of calcium and magnesium on cell wall and starch of dehydrated potato granules, J. Agric. Food Chem. 28 (2): 383-91.

7. Hester, E. E., Briant, A. M. and Personius, C. J., 1956. The effect of sucrose on the properties of some starches and flours, Cereal Chem. 33: 91-101.

8. Howling, D., 1980. The influence of the structure of starch on its rheological properties, Food Chem. 6 (1): 51-61.

9. Kayisu, K., Hood, L. F. and Vansoed, P. R., 1981. Characterization of starch and fiber of banana fruit, J. Food Sci. 46 (6): 1885-90.

10. MacMasters, M. M., 1964. Methods in Carbohydrates Chemistry, Vol IV: 233-40, Academic Press, New York, N. Y.

11. Osman, E. M., 1975. Interaction of starch with other components of food systems, Food Technol. 29 (4): $30-5$ and 44.

12. Robinson, P., 1955. Test of significance, Bull. of Statistical Res. Ser., Canada Dep. Agric.

13. Rodriguez-Sosa, E. J. and González, M. A., 1977. Effect of some food ingredients on various characteristics of instant tanier flakes and wheat flour, J. Agric. Univ. P.R. 61 (2): $234-41$.

14. - - and Parsi-Ros, O., 1982. Starch properties of Habanero yam (Dioscorea rotundata), J. Agr. Univ. P.R. 66 (1): 27-34.

15. —_— - and González, M. A., 1981. Effect of $\mathrm{pH}$ on pasting properties of Habanero (Dioscorea rotunda) yam starch, J. Agri. Univ. P.R. 65 (2): 154-9.

16. Schoch, T. J., 1964. Methods in Carbohydrates Chemistry, Vol. IV. 106-8, Academic Press, New York, N. Y.

17. _ 1969. Mechano-chemistry of starch, Wallerstein Laboratories Communications, 32 (9): 149-71, Wallerstein Laboratories, 125 Lake Avenue, Staten Island, N. Y. 